\title{
DIGITALCOMMONS
}

3-6-2019

\section{Should We Give Up on Causality?}

Tom Knapp

The Ohio State University, tomknapp5@gmail.com

Follow this and additional works at: https://digitalcommons.wayne.edu/jmasm

Part of the Applied Statistics Commons, Social and Behavioral Sciences Commons, and the Statistical Theory Commons

\section{Recommended Citation}

Knapp, T. (2018). Should we give up on causality? Journal of Modern Applied Statistical Methods, 17(2), eP2720. doi: 1551907445

This Invited Article is brought to you for free and open access by the Open Access Journals at DigitalCommons@WayneState. It has been accepted for inclusion in Journal of Modern Applied Statistical Methods by an authorized editor of DigitalCommons@WayneState. 


\section{INVITED ARTICLE Should We Give Up on Causality?}

\section{Tom Knapp}

The Ohio State University

Columbus, $\mathrm{OH}$

Keywords: Causality, randomization

\section{Introduction}

Researcher A randomly assigned forty members of a convenience sample of middle school students to one of five different amounts of remedial reading instructional minutes (eight students for each amount), determined the number of books each student subsequently chose to read, and carried out a test of the significance of the difference among the five mean numbers of books read. Researcher B had access to the school records for a random sample of forty middle school students, determined the number of minutes of remedial reading instruction each student received, the number of books that each student read, and calculated the correlation (Pearson product-moment) between number of minutes and number of books. Researcher A's study has a stronger basis for causality (internal validity). Researcher B's study has a stronger basis for generalizability (external validity). Which of the two studies contributes more to the advancement of knowledge?

Do you need to see the data before you answer the question? The raw data are the same for both studies:

$\begin{array}{rrrrrr}\text { ID } & \text { Minutes } & \text { Books } & \text { ID } & \text { Minutes } & \text { Books } \\ 1 & 75 & 5 & 6 & 75 & 15 \\ 2 & 75 & 10 & 7 & 75 & 15 \\ 3 & 75 & 10 & 8 & 75 & 20 \\ 4 & 75 & 10 & 9 & 125 & 10 \\ 5 & 75 & 15 & 10 & 125 & 15\end{array}$

doi: 10.22237/jmasm/1551907445 | Accepted: January 24, 2018; Published: March 6, 2019.

Correspondence: Tom Knapp, tomknapp5@gmail.com 


\section{TOM KNAPP}

$\begin{array}{rrrrrr}\text { ID } & \text { Minutes } & \text { Books } & \text { ID } & \text { Minutes } & \text { Books } \\ 11 & 125 & 15 & 26 & 225 & 25 \\ 12 & 125 & 15 & 27 & 225 & 25 \\ 13 & 125 & 20 & 28 & 225 & 25 \\ 14 & 125 & 20 & 29 & 225 & 30 \\ 15 & 125 & 20 & 30 & 225 & 30 \\ 16 & 125 & 25 & 31 & 225 & 30 \\ 17 & 175 & 15 & 32 & 225 & 35 \\ 18 & 175 & 20 & 33 & 275 & 25 \\ 19 & 175 & 20 & 34 & 275 & 30 \\ 20 & 175 & 20 & 35 & 275 & 30 \\ 21 & 175 & 25 & 36 & 275 & 30 \\ 22 & 175 & 25 & 37 & 275 & 35 \\ 23 & 175 & 25 & 38 & 275 & 35 \\ 24 & 175 & 30 & 39 & 275 & 35 \\ 25 & 225 & 20 & 40 & 275 & 40\end{array}$

Here are the results for the two analyses (using Excel and Minitab):

SUMMARY

$\begin{array}{rrrrr}\text { Group } & \text { Count } & \text { Sum } & \text { Mean } & \text { Variance } \\ 75 \text { mins } & 8 & 100 & 12.5 & 21.43 \\ 125 \text { mins } & 8 & 140 & 17.5 & 21.43 \\ 175 \text { mins } & 8 & 180 & 22.5 & 21.43 \\ 225 \text { mins } & 8 & 220 & 27.5 & 21.43 \\ 275 \text { mins } & 8 & 260 & 32.5 & 21.43\end{array}$

ANOVA

$\begin{array}{lrrrr}\text { Source of Variation } & \text { SS } & \text { df } & \text { MS } & \text { F } \\ \text { Between Groups } & 2000 & 4 & 500 & 23.33 \\ \text { Within Groups } & 750 & 35 & 21.43 & \\ \text { Total } & 2750 & 39 & & \end{array}$

Correlation between Minutes and Books $=0.853$

The regression equation is:

Books $=5.00+0.10$ Minutes 


\section{SHOULD WE GIVE UP ON CAUSALITY?}

\begin{tabular}{|c|c|c|c|c|}
\hline Predictor & Coe & & Standard error & t-ratio \\
\hline Constant & 5.0 & & 1.88 & 2.67 \\
\hline Minutes & 0.1 & & 0.0099 & 10.07 \\
\hline$s=4.44$ & $\mathrm{R}-\mathrm{sq}=$ & $72.7 \%$ & $R-s q(\operatorname{adj})$ & $=72.0 \%$ \\
\hline \multicolumn{5}{|c|}{ Analysis of Variance Table } \\
\hline SOURCE & DF & SS & MS & \\
\hline Regression & 1 & 2000 & 2000 & \\
\hline Error & 38 & 750 & 19.7 & \\
\hline Total & 39 & 2750 & & \\
\hline
\end{tabular}

The results are virtually identical. (Given that both approaches are subsumed under the general linear model, that is not surprising.) There is only that tricky difference in the $d f$ s associated with the fact that hours is discrete in the ANOVA (its magnitude never entered the analysis) and continuous in the correlation and regression analyses.

\section{But What About the Assumptions?}

Here is the overall frequency distribution for Books:

$\begin{array}{rr}\text { Books } & \text { Count } \\ 5 & 1 \\ 10 & 4 \\ 15 & 7 \\ 20 & 8 \\ 25 & 8 \\ 30 & 7 \\ 35 & 4 \\ 40 & 1\end{array}$

It appears normally distributed. Here is the frequency distribution of number of books read for each of the five groups: (This is relevant for homogeneity of variance in the ANOVA and for homoscedasticity in the regression.) 


\section{TOM KNAPP}

\begin{tabular}{|c|c|c|c|}
\hline Books & Count & Mins $=75$ & $n=8$ \\
\hline 5 & 1 & & \\
\hline 10 & 3 & & \\
\hline 15 & 3 & & \\
\hline 20 & 1 & & \\
\hline Books & Count & Mins $=125$ & $n=8$ \\
\hline 10 & 1 & & \\
\hline 15 & 3 & & \\
\hline 20 & 3 & & \\
\hline 25 & 1 & & \\
\hline Books & Count & Mins $=175$ & $n=8$ \\
\hline 15 & 1 & & \\
\hline 20 & 3 & & \\
\hline 25 & 3 & & \\
\hline 30 & 1 & & \\
\hline Books & Count & Mins $=225$ & $n=8$ \\
\hline 20 & 1 & & \\
\hline 25 & 3 & & \\
\hline 30 & 3 & & \\
\hline 35 & 1 & & \\
\hline Books & Count & Mins $=275$ & $n=8$ \\
\hline 25 & 1 & & \\
\hline 30 & 3 & & \\
\hline 35 & 3 & & \\
\hline 40 & 1 & & \\
\hline
\end{tabular}

Those distributions are as normal as they can be for eight observations per group. (They're actually the binomial coefficients for $n=3$.)

\section{So What?}

The "So what?" is that the conclusion is essentially the same for the two studies; i.e., there is a strong linear association between minutes of remedial reading instruction and number of books read. The regression equation for Researcher B's study can be used to predict books from minutes quite well for the population from which their sample was randomly drawn. They are likely to be only off by 5-10 books in number of books read, since the standard error of estimate, $s,=4.44$. Why do we need the causal interpretation provided by Researcher A's study? Isn't the greater generalizability of Researcher B's study more important than whether or not the effect of minutes on books is causal for the non-random sample? These data are 


\section{SHOULD WE GIVE UP ON CAUSALITY?}

admittedly artificial (for illustrative purposes). Real data are never that clean, but they could be.

\section{What is Typically Stated Regarding Causation, Correlation, and Prediction?}

The sources cited most often for distinctions among causation (using the terms "causality" and "causation" interchangeably), correlation, and prediction are classics written by philosophers such as Mill (1884) and Popper (1959); textbook authors such as Pearl (2000); and journal articles such as Hill (1965) and Holland (1986a) (with comments Rubin, 1986; Cox, 1986; Glymour, 1986; Granger, 1986; and rejoinder Holland, 1986b). However, consider Frakt (2009) and White (2010):

\section{Frakt (2009)}

In an unusual twist, Frakt (2009) argued causation may exist without correlation. (The usual minimum three criteria for a claim that $X$ causes $Y$ are strong correlation, temporal precedence, and non-spuriousness.) An example was given in which the true relationship between $X$ and $Y$ is mediated by a third variable $W$, where the correlation between $X$ and $Y$ is equal to zero.

\section{White (2010)}

White (2010) decried the endless repetition of "correlation is not causation."

He argued most knowledge is correlational knowledge; causal knowledge is only necessary when control is needed. Causation is a slippery concept, and correlation and causation go hand-in-hand more often than imagined.

In the spirit of this distinction between correlational knowledge and causal knowledge, can it be agreed the focus of research efforts should be on two nonoverlapping strategies: true experiments (randomized controlled trials) carried out on non-random samples, with replications wherever possible; and nonexperimental correlational studies carried out on random samples, also with replications?

What about the effect of smoking (firsthand, secondhand, thirdhand...) on lung cancer? It may be necessary to give up on causality even there. There are problems regarding the difficulty of establishing a causal connection between the two, even for firsthand smoking. See, for example, Spirtes, Glymour, and Scheines (2000, pp. 239-240). 


\section{TOM KNAPP}

\section{References}

Cox, D. R. (1986). Statistics and causal inference: Comment. Journal of the American Statistical Association, 81(396), 963-964. doi: 10.2307/2289066

Frakt, A. (2009, December 16). Causation without correlation is possible [web log post]. Retrieved from https://theincidentaleconomist.com/wordpress/causation-without-correlation-ispossible/

Glymour, C. (1986). Statistics and causal inference: Comment: Statistics and metaphysics. Journal of the American Statistical Association, 81(396), 964966. doi: $10.2307 / 2289067$

Granger, C. (1986). Statistics and causal inference: Comment. Journal of the American Statistical Association, 81(396), 967-968. doi: 10.2307/2289068

Hill, A. B. (1965). The environment and disease: Association or causation? Proceedings of the Royal Society of Medicine, 58(5), 295-300.

Holland, P. W. (1986a). Statistics and causal inference. Journal of the American Statistical Association, 81(396), 945-960. doi: 10.2307/2289064

Holland, P. W. (1986b). Statistics and causal inference: Rejoinder. Journal of the American Statistical Association, 81(396), 968-970. doi: 10.2307/2289064

Mill, J. S. (1884). A system of logic, ratiocinative and inductive: Being a connected view of the principles of evidence, and methods of scientific investigation. London, UK: Longmans, Green, and Co.

Pearl, J. (2000). Causality: Models, reasoning, and inference. New York, NY: Cambridge University Press.

Popper, K. (1959). The logic of scientific discovery. London, UK:

Routledge.

Rubin, D. B. (1986). Statistics and causal inference: Comment: Which ifs have causal answers. Journal of the American Statistical Association, 81(396), 961-962. doi: 10.2307/2289065

Spirtes, P., Glymour, C., \& Scheines, R. (2001). Causation, prediction, and search (2nd ed.). Cambridge, MA: The MIT Press. doi:

10.7551/mitpress/1754.001.0001

White, J. M. (2010, October 1). Three-quarter truths: Correlation is not causation [web log post]. Retrieved from http://www.johnmyleswhite.com/notebook/2010/10/01/three-quarter-truthscorrelation-is-not-causation/ 